BENTHAM OPEN
CrossMark
Content list available at: www.benthamopen.com/TOPSYJ/
DOI: $10.2174 / 1874350101811010184,2018,11,184-197$

RESEARCH ARTICLE

\title{
Cultural Tourism Behaviors: Enhancing the Influence of Tourists' Perceptions on Local Thai Food and Culture
}

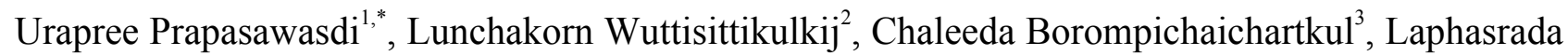
Changkaew ${ }^{4}$ and Muhammad Saadi ${ }^{5}$

${ }^{I}$ Technopreneurship and Innovation Management Program, Graduate School, Chulalongkorn University, Bangkok 10330, Thailand

${ }^{2}$ Department of Electrical Engineering, Faculty of Engineering, Chulalongkorn University, Bangkok 10330, Thailand

${ }^{3}$ Department of Food Technology, Faculty of Science, Chulalongkorn University, Bangkok 10330, Thailand

${ }^{4}$ Department of Researcher Affairs, Chulalongkorn University, Bangkok 10330, Thailand

${ }^{5}$ Department of Electrical Engineering, Faculty of Engineering, University of Central Punjab, Johar Town, Lahore, Pakistan

\section{Abstract:}

Background:

Tourist behavior plays a principle role in preserving the cultural heritage and supporting the economy of the local community. Local food is a significant factor for tourists and an important cultural aspect distinguishing one country from one another. To understand tourists' food decision making, this study investigates tourists' perceptions of local food.

\section{Methods:}

A mixed-method methodology used a concurrent transformative strategy. Qualitative research comprised in-depth interviews conducted with 15 local food specialists and 10 tourists; quantitative comprised survey structured questionnaires with a sample of 400 tourists travelling in Chiangmai, Thailand.

\section{Findings:}

The result revealed that tourists' perceptions comprising attitude, subject norm, perceived value and expectation factors positively affected the perception toward local food information. Regression analysis suggested that the four variables contributed $53.4 \%$ to the variation of local food. By employing the standardized coefficients as mentioned, the linear regression model was $\mathrm{Y}=$ $0.424 \mathrm{~A}-0.201 \mathrm{~S}+0.428 \mathrm{E}+0.234 \mathrm{P}$.

\section{Conclusion:}

Four factors affected tourists' perceptions towards local food as follows: (1) expectation towards local food information via media, (2) attitude of tourists towards local food, (3) perceived value of local food with the benefit, belief and nutrition of local food, and (4) subject norm towards local food; local food experts influence to tourists. All the factors lead tourists to perceive in local food and culture.

Keywords: Tourist perception, Tourist behavior, Local food, Culture tourism, Social influencer, Cultural heritage.

\footnotetext{
"Address correspondence to this author at the Technopreneurship and Innovation Management Program, Graduate School, Chulalongkorn University, 1405-1409 14 ${ }^{\text {th }}$ Floor, Chamchuri Square Building, Phayathai Road, Bangkok 10330, Thailand; Tel: +66816224471; E-mail: knotjung@gmail.com
} 


\section{INTRODUCTION}

Historically, local culture was preserved and transferred from one generation to another through word of mouth, storytelling, legends, beliefs and behavior. With the transformative advances in the transportation system and information technology over the past couple of decades, world boundaries are virtually shrinking to become more like a global village. Now tourists can explore local culture and cuisine more conveniently, learn about unfamiliar destinations and they have the opportunity to mingle with the local populations who possibly have different mindsets, upbringing, beliefs, languages, etc. Cultural information obtained by the tourists plays an important role in passing on local heritage to the next generation. Exchange of motivational information leads to positive heritage tourism, i.e. tourists are attracted to experiencing the places, artifacts and activities of the locals from the past [1]. Information sharing is popular in social communities to better understand the choices and preferences of each other. On the internet, not only humans but also things are connected through the Internet of Everything (IOE). Thus, cultural information can more easily be propagated across the globe.

Culture relates to the way of life in each region, and traditional food is unique and considered to be a signature of that place [2]. Food consumption has a broader scope and is documented as a collection of circumstantial and emerging social norms, where food not only aids nourishment but is also a way to associate with other people in social, cultural and political terms [3]. The consumption and partaking of local food are regarded as essential to attaining information about the local culture, geography, lifestyles and inhabitants' health [4]. Most tourists view the diverse culture and taste the local food that helps in stimulating local economic growth and infrastructure development, thus raising the living standards of the locals [5]. In essence, what the tourist is interested in is the different food culture, a factor for local development that also contributes to the enhancement of food culture [6]. The unique characteristics of local food are presented according to two trends: emerging tourism attractions and the ongoing movement of food-related behavior. Food is an integral part of travelers' behavior that may vary according to their interest in food [7]. Local food affects lifestyle with regard to consumer behavior and is a gateway to understanding a destination's cultural heritage, and traditional food culture $[2,7]$.

Local cuisine is one important factor influencing tourist decisions about the choice of destination, a place where they can experience a variety of cooking methods, ingredients and food presentations [8]. Local food, health care, the communication gap, and limited knowledge about food and culture among tourists are significant factors that require attention [9]. Given the above, the most important components in the perception of local food are taste, lifestyle, health, communications, knowledge, cooking method, ingredients and food presentation.

Cultural tourism has become one of the most important aspects of mass marketing, and it has witnessed rapid growth [10] due to the increased interest in arts, culture and history [11]. Advances in communication technology have made cultural food more perceptible [12]. In the past, cultural tourism centered on cultural sites as well as historical and metropolitan cities. However, a paradigm shift has occurred towards cultural experiences and the amalgamation of cultural tourism with other aspects of tourism. Cultural attractions are becoming tourist destinations [13]. The development of cultural tourism has been able to attract visitors to explore spectacular destinations.

Local people may take their culture for granted and it's the tourist who explores it, gets fascinated and enjoys the authentic experience. From the internet, a person can get a lot of information about the heritage, culture and cuisine of some regions; however, it's really hard to get real sensations out of this information. In order to promote local culture, local communities act as a means of promoting interesting and undiscovered destinations and specialties that are worth exploring [14].

A study of tourist behavior suggested that when researching the lifestyle, one is able to manage any individual profile, aspects and can predict behavior better than demographic variables [15]. The Theory of Planed Behavior (TPB) can be employed to focus on tourist behavior. TPB is a predictor of an individual's specific intention [16] and is one of the most cited for investigating human behavior: subject norms, attitudes and perceived behavior [17, 18]. TPB is widely known and used in an integrated model in intention-behavior [19] and also determines the individual decision [20] that shows behavior intention. To get the best design support website content, behavior in consumption of local food information is investigated under variable factors. The relevant information between perceivers and food culture was well-prepared and collated.

The objective of this study is to investigate tourists' perception of local food. The results were then applied to design web services supporting tourist service information. 
Many studies have addressed behavior. The study of personal attitude affecting food selection [21] is most important before tasting local food and drink [22]. Attitude is important to perceptions regarding local food. The principles behind perceiving food relate to taste, color, texture, and real image [2]. Intention to perceive influence people to conform [12]. Investigation of tourist satisfaction reveals the expectancy to revisit the destination [23]. The study of tourists' behavior indicates the attitude, motivation and behavior behind participants' food preference [24]. Therefore, to better understand how to attract tourists, tourist perceptions are investigated. Analysis of past research reveals there to have been no studies relating to the expectation of Thai local food culture. Empirical behavior or intentions of expression cause behavioral actions related to local food and the prediction of food information behavior. As concerns attitude and normative beliefs about tourists' behavior, the Theory of Planned Behavior (TPB) can more accurately predict this than the Theory of Reasoned Action (TRA) [25] - whereby the acceptance of tourists depends on their knowledge since the past and that useful information tries to understand behavior or to intervene to change behavior [26].

\section{LITERATURE REVIEW}

The role of information and communication technology (ICT) in promoting culture and heritage is crucial in the present era. The internet can be considered as the first source of information for tourists; thus, the first cultural perceptions develop from here. Now the perception trend has moved from small-scale individualized experiences to large-scale collective experiences. Therefore, it is safe to state that there is some relationship between the value of destination for cultural tourism and ICT [27]. Positive large-scale collective experiences and local heritage that are well promoted with the help of technology can indeed act as catalysts to add value to the cultural destination. Web service information can create an impact on tourists, and local food is one of the entities which a tourist looks for. Uniqueness of local food is a part of local culture and history [28]. Local food not only influences tourists to visit destinations of origin but also helps in developing affection and positive memories associated with the destination [29].

At present, most tourists search information, communicate and share their knowledge together. They travel for many reasons, often grouped into convenient categories such as health tourism, sport tourism, natural tourism, and food tourism. Food tourism is one of the attractive sensations, and food tourists are specifically divided through their needs and influence as relates to local food. Trends in local cuisine dramatically increase and tourists pay greater attention to both local life and cuisine. Thus, local food is a significant factor tourists are interested in and it is an influential factor in selecting their destination [30 - 32]. Destination image influences tourists to revisit destination and perceived value also satisfies and creates positive behavior intention among tourists [33 - 36]. All these reasons influence the decision as to their destination $[33,37]$. Tourists prepare information by searching before visiting the location [38]. Sources of food information to search for travel come from family, friends, face to face stories and anecdotes, magazines, journals, electronic media, and searching Google links to interesting food website [39 - 41].

Currently, most tourists perceive information by following famous food specialists on social media such as Facebook, Instagram, and Twitter. Such influencer food specialists affect tourists. On the other hand, following social media in real time; events and reviews can stimulate people who love to travel. All activities influence tourists' decisions about food selection during their visits and so presence on social media is necessary as it affects the decisionmaking process. Tourists have come to the local area and perceive the local environment as influencing their ability to eat healthy food [42]. Health care is another choice making tourists further interested in food. Food culture is a supplement to tourism since people are interested in local food, culture, and historical architecture. These make tourists feel like they are part of the region; in other words, learning in region, culture, tradition, and food while travelling define travel exactly. Besides, tourists have various attitudes concerning food [3, 43], and this also means that their motivations and interests tend towards the food to consume and the desire to search in advance of their experience while they travel.

Research has recommended many tourist patterns relating to attitudes, motivations and travel styles. Moreover, local cuisine is able to affect post-trip behavior, and is promoted through brand [44] and local food products presented as souvenirs from local retail stores or hotel restaurants [45]. Therefore, local food is a gateway to tourists understanding their visiting region, including the intangible heritage, culture and local food culture. This particularly concerns tourists looking at food [46]. It has also been found that tourists are much more interested in food and acquiring gastronomy $[47,48]$.

To better understand what positively influences tourists' food perceptions, tourist behavior is investigated. The attitudes and subject norms toward behavior are presented in difference behavior and are able to change many things 
influenced by behavior. This induces people to participate and stimulate to act the same way. Such behaviors occur when living in an environment with beliefs and motivations. The analyzing TPB is interesting, and the result can predict intention and behavior very well [17]. One study between TRA and TPB [49] found that the expectations from sample groups influenced both theory and the TPB was predictably accurate. This study uses TPB and expectation to investigate tourists' perceptions of local food.

This research studies the perceptions of local Thai food culture through information technology by using the adapted theory of planned behavior. The key factors of tourists' behavior in this study were the following independent variables: (i) Subjective norms, (ii) Attitude, (iii) Perceived value, and (iv) Expectation and the dependent variable was the intention to perceive. The expectation factor is the independent variable added in the TPB model to identify the factors involved in perceiving local food information. The TPB is a widely-used theory predicting behavior concerning subject norms, attitude, and perceived values [50], and many studies utilising it have been successful. Whilst the TPB predicts local food choice behavior [51], it also verifies the acceptable model in explaining consumers' behavior concerning sustainable food [52].

\subsection{Subject Norms of Local Food}

Subject norms present the identity and relationship of the communities including the way of life. Leaders of local communities influence the members. The traditions, the way of life and behavior in the communities also show the heritage culture from the past till the present. "Lifestyle is the pattern of individual and social behavior characteristics of an individual or a group." according to Ercan Sirikaya and Arch G. Woodside, 2005 [53]. It also shows the effect of the way of life on local food culture especially through the leaders of communities who have exercised influence in the transfer of knowledge and behavior throughout the generations.

Local food follows practical guidelines according to the people in a society; they follow a routine and are accepted in the local community. For example, when tourists visit Chiang Mai, they can experience the way of eating Khan-Tok. Locals hand down the way of life. So they have to follow these methods and rituals and transmit them culturall. Norms in the context of urban mobility have changed the pattern but still preserve the culture, so they are symbolic in the context of traditions and important occasions [54].

\subsection{Attitude Towards Local Food}

Attitude is a learning tendency that predicts and improves the behavior that is consistent with one's satisfaction or dissatisfaction [55]. Consequently, the attitude toward local food is important for the acceptance of local food, which is relevant in terms of taste, value and the benefits of food. The image of food indicates the identity of the local food itself [12]. Understanding the attitude of tourists can be used to divide customers to assess the market situation and select the target group to promote tourism. Personal attitude is the most important thing that makes tourists interested in consuming local food and drinks [56].

\subsection{Perceived Value towards Local Food}

Perceived value is a belief [50] involving the properties of local food. Perception of local food value in marketing is the recognition that tourists will be able to make repeated purchases, have taste experiences repeatedly or introduce them to others [57]. Perceived value toward local food has various components, including the quality of local food, nutritious benefits, health risks, and value for money [58]. Perceived value also plays an important role in influencing the market [59]. Perceived value toward local food involves properties such as taste, characteristics, and use of local food [60].

\subsection{Expectation Towards Local Food}

The expectation theory of Oliver (1977) [61] investigates the cognitive behavior of people and the effect of positive experience [62]. It also involves the expectations of customers who are satisfied and want to experience Northern Thai local cuisine [63]. This expectation also involves the normative [50], presenting significant information to the local community. The expectations of tourists in local food include traditional food and cuisine, social recreation and an important resource for local action [64], local food products, an exciting experience, knowledge, sensory appeal and health concerns $[2,65]$. 


\subsection{Intention to Perceive Local Food}

Intention to perceive investigates behavior; attitude, subject norm and perception-behavior [66] which is the immediate antecedent of actual behavior in perceiving local food information. Behavior intention predicts the decision with high accuracy [67] and the intention to perceive local food reflects tourist behavior as regards whether they want to try [68]. Tourist behavior mostly comprises obtaining information by searching from websites before the visit [69]. Managing local food information can stimulate people to join in local festivals or any activities and experiences in story-telling and impressive local food. The intention to perceive local food is also important to the local economy where tourists choose to visit as their destination [60].

Based on the stated previous research work, the conceptual framework to investigate the relationship between the independent and dependent variable can be summarized as shown in (Fig. 1).

Independent variables Dependent variable

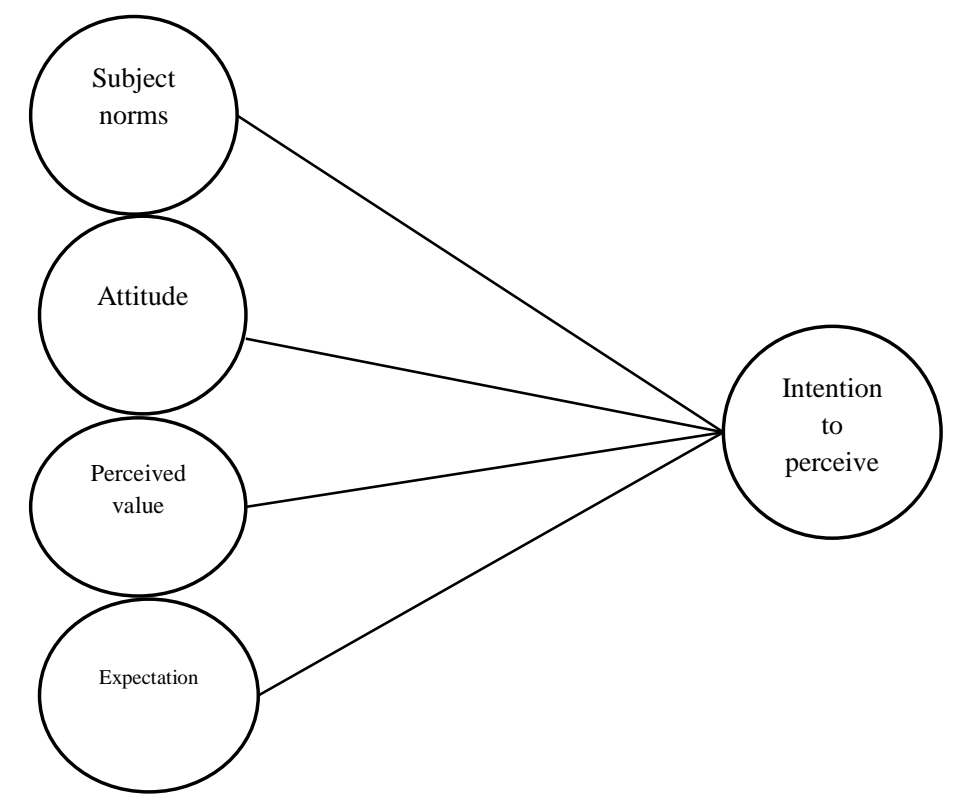

Fig. (1). Conceptual Framework Model.

\section{METHODOLOGY}

A mixed-method methodology using a concurrent transformative strategy was used for this study. In the first phase, in-depth, semi-structured qualitative interviews were conducted with 15 local food specialists and 10 tourists traveling more than 2-3 times per year. A snowball sampling technique was used to recruit participants in the qualitative study. Qualitative data were analyzed using content analysis technique. For the quantitative method in the second phase, a cross-sectional survey was undertaken using a structured questionnaire. A 5-point Likert scale from 1 (minimal importance) to 5 (most importance) was used to elicit participants' responses. The content validity of the questionnaire was assessed by three experts. The reliability was assessed using Cronbach's alpha and the value was 0.82 . Four hundred tourists were recruited from attractive travelling places in Chiangmai using a convenient sampling technique. Regression analysis was undertaken to identify the predicted factors for tourists' perceptions toward local food information, to experience local food and participate in festival and tradition. The factors investigated were Attitude toward local food, Subject norms of local food, Perceive value of local food and Expectation of local food information.

This study investigates the key factors and whether the independent variables - subject norm, attitude, perceive value and expectation influenced intention to perceive. The research hypotheses are following by;

Hypothesis 1 Subject norm influence intention to perceive.

Hypothesis 2 Attitude influence intention to perceive.

Hypothesis 3 Perceived Value influence intention to perceive. 
Hypothesis 4 Expectation influence intention to perceive.

\section{RESULTS}

From the qualitative results, the significant contents were analyzed into questionnaires surveying 400 tourists. The qualitative study results from interviews were as follows:

\subsection{Perception of Northern Thai Food}

The northern part of Thailand is mostly covered by green mountains, hills and misty jungles. The weather is relatively colder than the rest of the country. This region also serves as the origin of the major rivers in Thailand. The main occupation of the people living in these fertile and water abundant lands is farming, where vegetables and herbs are very important for cooking and the inhabitants have been practicing this occupation from generation to generation. One popular and easy-to-cook dish from this area is Nam-Prik, a hot sauce prepared from shrimp paste and spices served with various kinds of vegetables and sticky rice. The vegetables in the area are readily available and some indigenous ingredients are used to cook the food in accordance with local preferred tastes.

Not only the occupation but also the culture combine and influence the food characteristics. In the past, the Lanna Kingdom was profoundly influenced by its neighbors Myanmar, Thai Lue and Chiang Tung. This involved commercial activities and cultural exchanges among them. At present, much of the region has changed to modern cities, however, there are some local communities, notably Tai-Lue, Tai Yong and Tai-Khern which still practice the traditional way of life and have preserved their culture. Although each community may have their own unique identity, their connections are strong and deep-rooted. Therefore, local food is not specific to each community but rather represents the whole region. Among them, Tai-Khern has become a popular destination for tourists where they can enjoy and experience the traditional way of life, as well as the added value of a rich and long history. The government not only generously supports the Tai-Khern community in preserving their culture but also takes care of ancient constructions such as houses, temples which serve as centers for cultural exhibitions and festivals. Tourists can truly understand and can live in this 700-year-old way of life while the local people continue their simple and traditional way of life. Therefore, TaiKhern is an ideal community to present as a primary source of local cultural information with an emphasis on traditional food.

The culture in each community relates to the way of life, story-telling, attitudes, subject norms and behavior. One of the significant components identifying a region is local food. Geography and environment affect local food and traditions. The uniqueness of local food deeply connects with the culture, recipes, availability of ingredients and geographical locations. Attitude, subject norms and the perceived value of local food are associated with the culture. Attitude is the concept of thinking about culture, local food and perceptions about local food. Subject norms, in this study, define the values, beliefs, and behaviors of a specified group influenced by local mentors. In Thai culture, locals pay respect to local mentors. Local food specialists not only act as regulators but also transfer tacit knowledge to the communities and present local food characteristics to the communities. They exercise influence on their families, relatives and especially tourists who experience the local food of non-native societies. The eating style which is most popular among the locals is usually one of sitting around in a circle and eating main dishes with boiled vegetables. Traditionally, in festivals, there are some beliefs associated with the food. For instance, during Songkran (festival to celebrate the Thai New Year), people believe that eating jackfruit curry (Thai Ka-noon) will give heavenly support and future success. Songs or folksongs of the Northern region mostly tell of the way of life, some explain local food, such as it was eaten by locals who live on high mountains like Khao-Jee (Grilled rice) which is an easy to cook food. They believe that the ingredients and organic vegetables are useful along with their health benefits and are readily available in the northern areas of Thailand.

\subsection{Factors Persuading Tourist to Consume Local Food}

Essential factors from in-depth interviews show that tourists plan itineraries to meet their needs. These needs can be general travel, adventurous tourism, extreme and sports tourism, health tourism, seminar and business tourism, and conservative tourism. Mostly tourists receive information from different sources such as family, relatives, friends and travel agents. In the last 10 years, internet and social media are more widely used as a source of information which plays a key role in the decision making for tourists in selecting the destination and planning the activities during travel.

Information about the local food and its ingredients were not well known in the past, but at present, tourists have a variety of information points through the press and social media. When people go on vacation, they take photos of 
beautiful sights, restaurants and other lively activities and then share them with their family, friends and general audience. Thus, the tourist's perspective takes cues from their peers' reviews and is influenced by them; hence, social media plays a role in the decision making of vacationers. Recently, there has been demand for standards in diets as people are now more concerned about their health. When away from home, tourists experience different atmospheres and food. They don't want to fall ill or feel uncomfortable during their trip so they are concerned with the ingredients of the food as well. If the information about local food is presented in the desired way, then it will have a positive impact on tourism.

Food and cultural tourism are encouraged via media not only in Thailand but also in the Association of Southeast Asian Nations (ASEAN) region. The government aims to support tourism and in this regard, and efforts are being made to promote traditions, cultures, lifestyles, and local food.

\subsection{Tourist Information Resources}

One of the most important aspects of culture is the food. Queries surrounding local food have increased dramatically. Tourists used to search online resources about cooking local food specialties, buying local ingredients via Google, Trip Advisor, and social media: Facebook, Twitter, Instagram, as well as local food specialists or friends who have previously been to this area. Activities such as exhibitions, cultural events and festivals also help stimulate people to try and enjoy the local food in many ways.

\subsection{Interesting Local Food Information for Tourists}

Tourists pay attention to food characteristics such as the properties of materials, nutrition values, appetizing appearance and taste. The cooking method reveals about the secrets of the cooking process. While travelling, tourists eat local food, discover local food restaurants and enjoy every local signal. The local food image attracts tourists to the experience. Organic ingredients are considered to be good for health and one such ingredient predominantly used in Thai food is Makhean. This attracts tourists to try the natural food which is not only mouthwatering but also beneficial. Food recipes are transferred from family and friends and then adjusted as per taste.

\subsection{Quantitative Study Results}

The quantitative findings from the analysis of statistical data after collecting information from 400 tourists in Chiang Mai Province are provided as follows. Of the 400 respondents, $30.5 \%$ are male and $69.5 \%$ are female. $47 \%$ of the respondents falls into the age group of 26-35, and 25\% between $36-45$. Tourists find information about local food by searching various sources. The results of this study are divided into 2 groups: The first group used electronic media including websites, social media and blogs (40\%). For the second group, the information was coming from family/friends, travel agents, radio and TV. Table 1 shows the statistics for these two groups.

Table 1. Methods of information search

\begin{tabular}{|c|c|}
\hline Entity & Percentage (\%) \\
\hline Electronic media (Group 1) & - \\
\hline Websites & 89.0 \\
\hline Social media such as Facebook, Instagram & 80.3 \\
\hline Blogs & 40.0 \\
\hline Others (Group 2) & - \\
\hline Family/friends & 75.0 \\
\hline Travel agency & 38.8 \\
\hline TV & 15.0 \\
\hline Radio & 14.5 \\
\hline
\end{tabular}

Three experts reviewed the evaluation strategies and summary. To identify the general degree of the agreement among the judges over each statement, the index of Item-Objective Congruence (IOC) was applied.

According to the calculation with IOC developed by [70, 71], the obtained IOC value average was 0.95 . It was found that 5 factors of behaviors (i.e. subject norms, attitude, perceived value, expectation, and intention) were of the highest scale. Following discussion with experts in the field and with the IOC value between $0.50-1.00$, the researcher constructed the factors which measure the regression analysis in Table $\mathbf{2}$. 
Table 2. Mean and Standard Deviation of Factors.

\begin{tabular}{|c|c|c|c|c|}
\hline Item & Factors & $\bar{X}$ & SD & $\boldsymbol{r}_{x y}$ \\
\hline 1 & Subject norms of local food & 3.70 & 0.815 & 0.955 \\
\hline 2 & Attitude toward local food & 3.77 & 0.790 & 0.955 \\
\hline 3 & Perceive value of local food & 3.79 & 0.826 & 0.955 \\
\hline 4 & Expectation on local food information & 3.76 & 0.804 & 0.955 \\
\hline 5 & Intention to perceive local food & 3.64 & 0.886 & 0.956 \\
\hline
\end{tabular}

$* * r_{x y}$ greater than 0.80 .

The reliability of each factor was calculated based on parameters in the model using the formula suggested by [72]. Reliability values $>0.8$ were considered to indicate good internal consistency

Multiple regression analysis allows us to use more than one predictive factor. We distinguish the cause and analyze the influence of each variable. In this paper, on the influence of the intention to perceive local food information factor, the regression analysis of the relationship between independent variables is as follows. The result of multiple linear regression analysis showed that the $\mathrm{F}$ calculated value is 115,387 ( $\mathrm{df1} 4 \mathrm{df} 2=395 ; \alpha=5 \%$ ), with the significance value of 0.000 which is smaller than 0.05 . This indicates that the intention to perceive local food depends on the attitude toward local food (A) Beta $=.424$, Subject norms of local food (S) Beta $=-.201$, Expectations of local food information (E) Beta $=.428$, Perceived value of local food $(\mathrm{P})$ Beta $=.234$. The value of the coefficients of determination (Adjust R2) stood at 0.534 . It can be stated that the four variables contributed $53.4 \%$ to the variation of intention to perceive local food, while the remaining $46.6 \%$ seems to be determined by other factors not included in the analysis model. By employing the standardized coefficients as mentioned in Table $\mathbf{3}$, the linear regression model is $\mathrm{Y}=$ $0.424 \mathrm{~A}-0.201 \mathrm{~S}+0.428 \mathrm{E}+0.234 \mathrm{P}$. The results showed that the model is multicollinearity. There is a correlation between the four dependent factors and one independent factor. The hypothesis result is Ho is rejected, H1 is accepted.

Table 3. Multiple linear regression analysis.

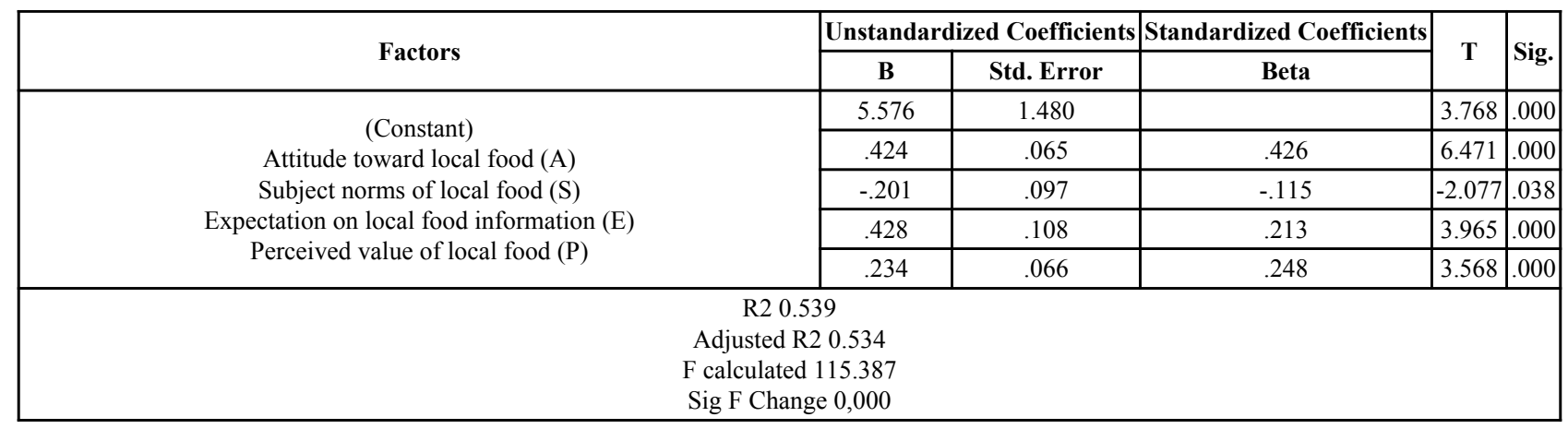

\section{DISCUSSION}

The findings of the current study give insights into the effective factors behind the perception of local food; subject norm, attitude, perceived value and expectation all are effects the perception of local food. The result is shown in Fig. (2). This study also shows that four factors have influenced the intention to perceive local food information at 53.4\%. The result also represents the direction toward perception of local food information. The attitudes $(42.4 \%)$, the expectations $(42.8 \%)$, and the perceived value $(23.4 \%)$ followed the same direction while the subject norm $(-20.1 \%)$ followed the opposite direction. This means that local food specialists influence tourists. The effected subject norm considered reliable and clearly labelled information from local food specialists to attract tourists to experience and enjoy local food. For example, a photo with celebrities attracts more people to try, while living in an environment can induce consumption, such as northern neighbors, living in the north or being near local restaurants or those with close northern friends. In contrast, the attitude is affected by the traditions or festivals encouraging tourists to know and learn more about local food. Advertising helps influence perceptions of local wisdom, arts and culture. The conservation patterns offer local cuisine in an interesting way and express the identity of the food. The perceived value also affects the intention to perceive information. The use and benefit of raw material, the nutrition and the source of growing vegetables enhance tourists' interest. All the above-mentioned are tourists' expectations that can be further easily shared in terms of their experience and knowledge. 


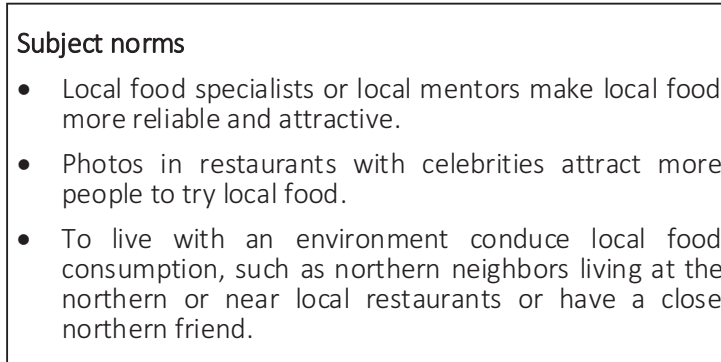

- Tttitude
- and learn about local food.
- Northern local food advertisement helps to gain local
wisdom, arts and culture.
- Conservation of northern local food patterns such as
khan-tok, banana leaf, and teak leaf offer a taste of
local northern cuisine in an interesting way and
expressesthe identity of the food.

\section{Perceived value}

- The vegetables and garnishing used in local cooking makes consumer believe that it is a nutritious food.

- Sources of growing vegetables, herbs of the north reveal native stories.

- Vegetables and herbs used in northern cuisines are their identity along with its nutritional benefits of the food.

- Knowing the nutritional value of food, the tourists want to convey the knowledge of the health benefits of northern local food to broader audience which helps transfer of information to other conveniently.

\footnotetext{
Expectation

- Online communities contribute to convey local information.

- A system for storing northern local food databases to support searching information any time.

- Using online tools for sharing information all the time makes the knowledge transfer.
}

\footnotetext{
d

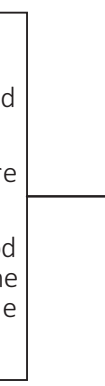


The tourists' attitude is positive through local food information through local mentors, experience and the transfer of their knowledge together. They are interested in traditions and festivals, activities, the story-telling surrounding local food, and activities of communication. We can see that there many attractive aspects for tourists concerning local food $[2,3,43,47,48]$. Perceiving the value of local food information by tourists is one of the most significant factors. Tourists are interested in the characteristics, taste, and nutrition of local food [25]. Regarding the subjective norms, local food specialists have influenced and attract tourists, and they are willing to participate in local activities and local food experience. The conservative styles and the presentation further draw in tourists $[1,4,8]$.

There are four parties to benefit from this study: tourists, local people, local communities and the social economy. The local information was directly gathered from locals with greater connection with tourists. Therefore, this makes it easy for the tourists to make decisions on experiencing local food. Further, when they share their experience with others the local food information will be more widely dispersed and known. Meanwhile, tourists can also learn about different cultures and make local communities influence both locals and tourists. The local communities are supported by tourists, organization tourism and government to prepare many attractive activities such as traditions, festivals, and exhibitions to welcome visitors. The social economy earned more benefit and the local communities were able to be self-sufficient. This is able to sustain local Thai food.

\section{CONCLUSION}

Rapid advances in digital technology have made it easier than ever for people to go online and connect globally. This allows people from different countries, different regions or even different towns to learn and share their unique culture and lifestyles through websites, social media, mobile applications, among others. As tourists, people can explore and discover places to go to, what to see and where to eat via the internet prior to their traveling to the destination. Research has shown that gastronomy can be a primary motivation for tourists when choosing their destination. Therefore, government authorities and research institutions in some countries work together and use local food and culture as the main policy when promoting the tourist industry.

In Thailand, food and cultural tourism is highly successful in most regions. Although the northern region of Thailand, especially Chiang Mai, is among the most popular tourist destinations, northern Thai food is barely known world-wide. In this work, we aim to promote local food in Chiang Mai through digital technology. We have developed a study platform based on the TPB model to obtain salient factors that enhance tourists' perceptions of local food information. Our study reveals that there are four key factors, according to the highest mean scores of each factor: 1) expectations to communicate online, to convey local information, to store local food information in the system and to share information with others; 2) attitudes of wanting to know the traditions or festival tendencies of tourists, to learn about local food and to advertise northern Thai local food and their special features that attract tourists to experience it; 3) perceived value from vegetables and garnishing, sources of vegetables and herbs, nutritional benefits in local food and knowledge sharing in nutritional value; and 4) subject norms influenced by local food specialists, photos and environments. All factors affect tourists when perceiving local food information and these results are emphasized by local food specialists who pay attention to food properties, value, characteristics and the way of diffusing information.

In the findings, the factors of Northern Thai local food information were used to arrange the contents on the website and storage categories into an efficient and convenient data system. Thus, this system can also be used for all local food information in each region. Another advantage is the heritage and useful local food culture information. The website is a social digital community which is the best way to stimulate local communities full of history and information to serve the increasing cultural tourism, and this also results in local communities becoming well-known. This supports important information not only useful for academic but also government reasons to receive a reliable system.

In the future, a reliable system will help to enhance publicity with the help of technology such as the internet and this will change the cultural tourism world.

\section{LIMITATION}

This research investigated four hundred Thai tourists who were mostly used to northern Thai local food. In the future, the research should be extended by surveying foreign tourists with the support of advanced communication technology to promote tourism and cultural exchanges. 


\section{ETHICS APPROVAL AND CONSENT TO PARTICIPATE}

Not applicable.

\section{HUMAN AND ANIMAL RIGHTS}

No animals/humans were used or mistreated for this research.

\section{CONSENT FOR PUBLICATION}

Not applicable.

\section{CONFLICT OF INTEREST}

The authors declare that they have no conflict of interest, financial or otherwise.

\section{ACKNOWLEDGEMENTS}

Declared none.

\section{REFERENCES}

[1] Le Le, De Urioste-Stone S, Holmes NC. Exploring African American, Latino, and Asian motivations to visit a heritage site: A case study of George Washington carver national. J Ethnogr Qual Res 2016; 11(1): 55-71.

[2] Kim YG, Eves A, Scarles C. Building a model of local food consumption on trips and holidays: A grounded theory approach. Int J Hospit Manag 2009; 28(3): 423-31. [http://dx.doi.org/10.1016/j.ijhm.2008.11.005]

[3] Mak AHN, Lumbers M, Eves A, Chang CYR. Factors influencing tourist food consumption. Int J Hospit Manag 2012; 31(3): 928-36. [http://dx.doi.org/10.1016/j.ijhm.2011.10.012]

[4] Feldmann C, Hamm U. Consumers' perceptions and preferences for local food: A review. In: Food Quality and Preference. 2015; 40: pp. (3)152-64. Part A:

[5] Barrett M, Davidson E, Prabhu JC, Vargo S. Service innovation in the digital age: Key contributions and future directions. MIS Quarterly 2015; 39(1): 135-54. [http://dx.doi.org/10.25300/MISQ/2015/39:1.03]

[6] Bessiere J, Tibere L. Traditional food and tourism: French tourist experience and food heritage in rural spaces. J Sci Food Agric 2013; 93(14): 3420-5.

[http://dx.doi.org/10.1002/jsfa.6284]

[7] Björk P, Kauppinen-Räisänen H. Local food: A source for destination attraction. Int J Contemp Hosp Manag 2016; $28(1)$ : $177-94$. [http://dx.doi.org/10.1108/IJCHM-05-2014-0214]

[8] Jalis MH, Che D, Markwell K. Utilising local cuisine to market malaysia as a tourist destination. Procedia Soc Behav Sci 2014; 144: 102-10. [http://dx.doi.org/10.1016/j.sbspro.2014.07.278]

[9] Cohen E, Avieli N. Food in tourism: Attraction and Impediment. Ann Tour Res 2004; 31(4): 755-78. [http://dx.doi.org/10.1016/j.annals.2004.02.003]

[10] Duhme L. Cultural Tourism: Case study portugal. Hamburg: Diplomica Verlag 2012.

[11] Liu Y-D. Cultural events and cultural tourism development: Lessons from the European capitals of culture. Eur Plann Stud 2014; 22(3): 498-514.

[http://dx.doi.org/10.1080/09654313.2012.752442]

[12] Cotillon C. Traditional food: A better compatibility with industry requirements. J Sci Food Agric 2013; 93(14): 3426-32. [http://dx.doi.org/10.1002/jsfa.6352]

[13] Rosemary Rice M. Marketing cultural and heritage tourism: A World of opportunity museum store association. Routledge 2016. [N.p.]

[14] Seaton P, Yamamura T. Japanese popular culture and contents tourism - introduction. Jpn Forum 2015; $27(1)$ : 1-11. [http://dx.doi.org/10.1080/09555803.2014.962564]

[15] Schul P, Crompton JL. Search behavior of international vacationers: Travel-specific lifiestyle and sociodemographic variables. J Travel Res 1983; 22(2): 25-30. [http://dx.doi.org/10.1177/004728758302200206]

[16] Mathieson K. Predicting user intentions: Comparing the technology acceptance model with the theory of planned behavior. Inf Syst Res 1991; 2(3): 173-91.

[http://dx.doi.org/10.1287/isre.2.3.173]

[17] Ajzen I. The theory of planned behaviour: Reactions and reflections. Psychol Health 2011; 26(9): $1113-27$. [http://dx.doi.org/10.1080/08870446.2011.613995] 
[18] Wu J-H, Cheng C-M, Cheng P-J. Behavioral intention toward urban eco-land performance assessment models using TPB tests. J Bus Res 2015; 68(4): 771-6. [http://dx.doi.org/10.1016/j.jbusres.2014.11.026]

[19] Yoon C. Theory of planned behavior and ethics theory in digital piracy: An integrated model. J Bus Ethics 2011; $100(3)$ : $405-17$. [http://dx.doi.org/10.1007/s10551-010-0687-7]

[20] Conner M, Armitage CJ. Extending the theory of planned behavior: A review and avenues for further research. J Appl Soc Psychol 1998; 28(15): 1429-64. [http://dx.doi.org/10.1111/j.1559-1816.1998.tb01685.x]

[21] Brown L, Edwards J, Hartwell H. A taste of the unfamiliar. Understanding the meanings attached to food by international postgraduate students in england. Appetite 2010; 54(1): 202-7. [http://dx.doi.org/10.1016/j.appet.2009.11.001]

[22] Kim YH, Kim M, Goh BK. An examination of food tourist's behavior: Using the modified theory of reasoned action. Tour Manage 2011; 32(5): 1159-65. [http://dx.doi.org/10.1016/j.tourman.2010.10.006]

[23] Hui TK, Wan D, Ho A. Tourists'satisfaction, recommendation and revisiting Singapore. Tour Manage 2007; 28(4): 965-75. [http://dx.doi.org/10.1016/j.tourman.2006.08.008]

[24] Chang RCY, Kivela J, Mak AHN. Food preferences of chinese tourists. Ann Tour Res 2010; 37(4): 989-1011 [http://dx.doi.org/10.1016/j.annals.2010.03.007]

[25] Han H, Lee S, Lee CK. Extending the theory of planned behavior: Visa exemptions and the traveller decision-making process. Tour Geogr 2011; 13(1): 45-74. [http://dx.doi.org/10.1080/14616688.2010.529930]

[26] Vinokur AD, Van Ryn M. Social support and undermining in close relationships: Their independent effects on the mental health of unemployed persons. J Pers Soc Psychol 1993; 65(2): 350. [http://dx.doi.org/10.1037/0022-3514.65.2.350]

[27] Valčić M, Domšić L. Information technology for management and promotion of sustainable cultural tourism. Informatica (03505596) 2012; 36(2): 131-6.

[28] Giampiccoli A, Kalis JH. Tourism, food, and culture: Community-Based tourism, local food, and community development in Mpondoland. Cult Agric Food Environ 2012; 34(2): 101-23. [http://dx.doi.org/10.1111/j.2153-9561.2012.01071.x]

[29] Alderighi M, Bianchi C, Lorenzini E. The impact of local food specialities on the decision to (re) visit a tourist destination: Market-expanding or business-stealing? Tour Manage 2016; 57: 323-33 [http://dx.doi.org/10.1016/j.tourman.2016.06.016]

[30] Wijaya S, King B, Morrison A, Huong Nguyen T. Destination encounters with local food: The experience of international visitors in Indonesia. Tour Cult Commun 2017; 17(2): 79. [http://dx.doi.org/10.3727/109830417X14966810027526]

[31] Bencivenga A, Dalterio Vollaro P, Forte F, Maria Giampietro G, Percoco A. Food and wine tourism in Basilicata. Agric Agric Sci Procedia 2016; 8: 176-85.

[http://dx.doi.org/10.1016/j.aaspro.2016.02.091]

[32] Kivela J, Crotts JC. Tourism and gastronomy: Gastronomy's influence on how tourists experience a destination. J Hosp Tour Res (Wash DC) 2006; 30(3): 354-77. [http://dx.doi.org/10.1177/1096348006286797]

[33] Ramseook-Munhurrun P, Seebaluck VN, Naidoo P. Examining the structural relationships of destination image, perceived value, tourist satisfaction and loyalty: Case of mauritius. Procedia Soc Behav Sci 2015; 175: 252-9. [http://dx.doi.org/10.1016/j.sbspro.2015.01.1198]

[34] Stylos N, et al. Destination images, holistic images and personal normative beliefs: Predictors of intention to revisit a destination. Tour Manage 2016; 53: 40-60.

[http://dx.doi.org/10.1016/j.tourman.2015.09.006]

[35] Zhang H, et al. Destination image and tourist loyalty: A meta-analysis. Tour Manage 2014; 40: $213-23$. [http://dx.doi.org/10.1016/j.tourman.2013.06.006]

[36] Nicoletta R, Servidio R. Tourists' opinions and their selection of tourism destination images: An affective and motivational evaluation. Tour Manag Perspect 2012; 4: 19-27. [http://dx.doi.org/10.1016/j.tmp.2012.04.004]

[37] Vajirakachorn T, Chongwatpol J. Application of business intelligence in the tourism industry: A case study of a local food festival in Thailand. Tour Manag Perspect 2017; 23: 75-86 [http://dx.doi.org/10.1016/j.tmp.2017.05.003]

[38] Chung N, Han H. The relationship among tourists' persuasion, attachment and behavioral changes in social media. Technol Forecast Soc Change 2017; 123: 370-80. 
[http://dx.doi.org/10.1016/j.techfore.2016.09.005]

[39] Holt J, Rumble NJ, Telg R, Lamm A. The message or the channel: An experimental design of consumers' perceptions of a local food message and the media channels used to deliver the information. J App Comm 2015; 99(4): 2. [http://dx.doi.org/10.4148/1051-0834.1053]

[40] Westerman D, Spence PR, Van Der Heide B. Social media as information source: Recency of updates and credibility of information. J Comput Mediat Commun 2014; 19(2): 171-83. [http://dx.doi.org/10.1111/jcc4.12041]

[41] Mangold WG, Faulds DJ. Social media: The new hybrid element of the promotion mix. Bus Horiz 2009; 52(4): $357-65$. [http://dx.doi.org/10.1016/j.bushor.2009.03.002]

[42] Belon AP, Nieuwendyk LM, Vallianatos H, Nykiforuk CI. Perceived community environmental influences on eating behaviors: A Photovoice analysis. Soc Sci Med 2016; 171: 18-29. [http://dx.doi.org/10.1016/j.socscimed.2016.11.004]

[43] Pesonen J, Komppula R, Kronenberg C, Peters M. Understanding the relationship between push and pull motivations in rural tourism. Tour Rev 2011; 66(3): 32-49. [http://dx.doi.org/10.1108/16605371111175311]

[44] Pérez Gálvez JC, Jaramillo Granda M, Lopez-Guzman T, Reinoso Coronel J. Local gastronomy, culture and tourism sustainable cities: The behavior of the American tourist. Sustainable Cities and Society 2017; 32: 604-12. [http://dx.doi.org/10.1016/j.scs.2017.04.021]

[45] Swanson KK, Timothy DJ. Souvenirs: Icons of meaning, commercialization and commoditization. Tour Manage 2012; 33(3): 489-99. [http://dx.doi.org/10.1016/j.tourman.2011.10.007]

[46] Yurtseven HR, Kaya O. Local Food In Local Menus: The case of Gokceada. Tourismos 2011; 6(2)

[47] López-Guzmán T, Patricia Uribe Lotero C, Claudio Pérez Gálvez J, Ríos Rivera I. Gastronomic festivals: Attitude, motivation and satisfaction of the tourist. Br Food J 2017; 119(2): 267-83. [http://dx.doi.org/10.1108/BFJ-06-2016-0246]

[48] Sánchez-Cañizares SM, López-Guzmán T. Gastronomy as a tourism resource: profile of the culinary tourist. Curr Issues Tour 2011; 15(3): $229-45$.

[http://dx.doi.org/10.1080/13683500.2011.589895]

[49] Ajzen I, Madden TJ. Prediction of goal-directed behavior: Attitudes, intentions, and perceived behavioral control. J Exp Soc Psychol 1986; 22(5): 453-74.

[http://dx.doi.org/10.1016/0022-1031(86)90045-4]

[50] Ajzen I. The theory of planned behavior. Organ Behav Hum Decis Process 1991; 50(2): 179-211. [http://dx.doi.org/10.1016/0749-5978(91)90020-T]

[51] Shin YH, Hancer M. The role of attitude, subjective norm, perceived behavioral control, and moral norm in the intention to purchase local food products. J Foodserv Bus Res 2016; 19(4): 338-51. [http://dx.doi.org/10.1080/15378020.2016.1181506]

[52] Han Y, Hansen H. Determinants of Sustainable Food Consumption: A meta-analysis using a traditional and a structura equation modelling approach. Int J Psychol Stud 2012; 4(1): 22.

[http://dx.doi.org/10.5539/ijps.v4n1p22]

[53] Sirakaya E, Woodside AG. Building and testing theories of decision making by travellers. Tour Manage 2005; 26(6): 815-32. [http://dx.doi.org/10.1016/j.tourman.2004.05.004]

[54] Van Westering J, Poria Y, Liapis N. Promoting the links between food and heritage as a resource for tourism: The integration of food and heritage through story telling. in World Tourism Organization Conference Proceedings (eds.), Local Food \& Tourism International Conference. 2000

[55] McCarty JA, Shrum L. The recycling of solid wastes: Personal values, value orientations, and attitudes about recycling as antecedents of recycling behavior. J Bus Res 1994; 30(1): 53-62. [http://dx.doi.org/10.1016/0148-2963(94)90068-X]

[56] Kim YH, Kim M, Goh KB, Antun MB. The role of money: The impact on food tourists' satisfaction and intention to revisit food events. J Culinary Sci Technol 2011; 9(2): 85-98. [http://dx.doi.org/10.1080/15428052.2011.580708]

[57] Parasuraman A, Grewal D. The impact of technology on the quality-value-loyalty chain: A research agenda. J Acad Mark Sci 2000; 28(1): 168. [http://dx.doi.org/10.1177/0092070300281015]

[58] Sweeney JC, Soutar GN, Johnson LW. Are satisfaction and dissonance the same construct? A preliminary analysis. J Consum Satisf Dissatisfaction Complain Behav 1996; 9: 138-43.

[59] Hsu C-L, Lin JC-C. What drives purchase intention for paid mobile apps? - An expectation confirmation model with perceived value. Electron Commerce Res Appl 2015; 14(1): 46-57. [http://dx.doi.org/10.1016/j.elerap.2014.11.003] 
[60] Roininen K, Arvola A, Lähteenmäki L. Exploring consumers' perceptions of local food with two different qualitative techniques: Laddering and word association. Food Qual Prefer 2006; 17(1): 20-30. [http://dx.doi.org/10.1016/j.foodqual.2005.04.012]

[61] Oliver RL. Effect of expectation and disconfirmation on postexposure product evaluations: An alternative interpretation. J Appl Psychol 1977; 62(4): 480-6. [http://dx.doi.org/10.1037/0021-9010.62.4.480]

[62] Brown SA, Venkatesh V, Kuruzovich J, Massey PJ. Expectation confirmation: An examination of three competing models. Organizational Behavior and Human Decision Processes 2008; 105(1): 52-66. [http://dx.doi.org/10.1016/j.obhdp.2006.09.008]

[63] Chimbanrai H, Wongsaroj R. Potential of local food and guidelines for tourism promotion through local food of nan province. Journal of International and Thai Tourism 2015; 11(1): 37-53.

[64] Bessière J. Local development and heritage: Traditional food and cuisine as tourist attractions in rural areas. Sociol Ruralis 1998; 38(1): 21-34. [http://dx.doi.org/10.1111/1467-9523.00061]

[65] Brown C. Consumers' preferences for locally produced food: A study in southeast Missouri. Am J Altern Agric 2009; $18(4)$ : $213-24$. [http://dx.doi.org/10.1079/AJAA200353]

[66] Dunstan DA, Covic T, Tyson GA. What leads to the expectation to return to work? insights from a Theory of Planned Behavior (TPB) model of future work outcomes. Work 2013; 46(1): 25-37.

[67] Ajzen I, Fishbein M. The prediction of behavioral intentions in a choice situation. J Exp Soc Psychol 1969; 5(4): 400-16. [http://dx.doi.org/10.1016/0022-1031(69)90033-X]

[68] Ryu K, Han H. Predicting tourists' Intention to try local cuisine using a modified theory of reasoned action: The oase of new orleans. J Travel Tour Mark 2010; 27(5): 491-506.

[http://dx.doi.org/10.1080/10548408.2010.499061]

[69] Jacobsen JKS, Munar AM. Tourist information search and destination choice in a digital age. Tour Manag Perspect 2012; 1(Suppl. C): 39-47. [http://dx.doi.org/10.1016/j.tmp.2011.12.005]

[70] Manasam M. Lanna dance from the past to the modern time: Journal of fine arts. Chiang Mai University 2008; 1(2): 72-81.

[71] Rovinelli R J, Hambleton R K. The use of content specialists in the assessment of criterion-referenced test item validity: 1977. Dutch J Edu Res 1977.

[72] Keith G. Calkins, Statistical Methods in Education and Psychology. $3^{\text {rd }}$ ed. New York: Allyn \& Bacon 2005.

\section{(C) 2018 Prapasawasdi et al.}

This is an open access article distributed under the terms of the Creative Commons Attribution 4.0 International Public License (CC-BY 4.0), a copy of which is available at: (https:/creativecommons.org/licenses/by/4.0/legalcode). This license permits unrestricted use, distribution, and reproduction in any medium, provided the original author and source are credited. 